\title{
Cultivating entrepreneurial culture among students in Malaysia
}

\author{
Zubair Hassan, Muneeb Khan Lashari, Abdul Basit
}

\begin{abstract}
A B S T R A C T
Objective: The objective of the article is to examine the factors influencing the cultivation of entrepreneurship culture among private higher education institutions in Malaysia.

Research Design \& Methods: A sample of 300 students from private higher education institutions in Cyberjaya, Malaysia, was selected using a convenient sampling technique. The data were analysed using structural equation modeling via AMOS, 22.0.

Findings: The result of the study indicates that empowerment is the only factor that has a positive and significant effect on cultivating entrepreneurial culture. We found that all other factors have no significant effect on cultivating entrepreneurial culture in the studied context.

Implications \& Recommendations: This study will enable education institutions to foster the entrepreneurial spirit among their students by focusing on empowering the students to carry out their tasks. This study recommends empowering students in their learning to promote entrepreneurial culture through the curriculum, assessment designs, and industrial engagement.
\end{abstract}

Contribution \& Value Added: This study contributes to the existing literature on promoting entrepreneurial culture among students by establishing the key determinants of entrepreneurial culture through risk-taking behaviour, innovation, creativity, and empowerment. One of the unique aspects of this research is that these four factors are studied together and tested based on what academic institutions in Malaysia do to cultivate entrepreneurial culture among the students.

Article type: research article

Keywords: $\quad$ entrepreneurial culture; creativity; risk-taking behaviour; empowerment; innovation JEL codes: $\quad$ 015, P47, Q01, Z12

Received: 30 May $2020 \quad$ Revised: 20 November $2020 \quad$ Accepted: 23 November 2020

\section{Suggested citation:}

Hassan, Z., Lashari, M.K., \& Basit, A. (2021). Cultivating entrepreneurial culture among the students in Malaysia. Entrepreneurial Business and Economics Review, 9(1), 119-136. https://doi.org/10.15678/EBER.2021.090108

\section{INTRODUCTION}

The growing awareness and demand for small and medium-sized enterprises - along with the importance of entrepreneurial activities - has triggered the research on entrepreneurship among scholars due to the significant effect of entrepreneurial activities on economic developments (Block, Fisch, \& Van Praag, 2017). In the past, some argued and debated on various issues associated with entrepreneurship, mostly how entrepreneurs impact 'job creation, healthy competition, economic growth, promotion of an 'inclusive' society by creating chances for people who have difficulties finding jobs and, last but not least, innovation' (Block et al., 2017, p. 61). Many developed and developing countries have allocated and spent vast amounts to promote and cultivate entrepreneurship culture (Acs et al., 2016). Governments like Malaysia formulated policies to cultivate entrepreneurship through education, access to finance, and business transfer facilities by subsidising entrepreneurship to decrease fear of failure and encourage innovation (Ariffin, Baqutayan, \& Mahdzir, 2018).

Today, we see that entrepreneurial culture is a catchy concept promoted by scholars and governments to motivate economic growth and tackle unemployment issues (Van der Westhuizen, 
2017). Entrepreneurial culture is seen as an important contributor to the success of the country, so organisations - especially academic institutions - educate and train future generations to become entrepreneurs (Henry, Hill, \& Leitch, 2017). Entrepreneurial culture was emphasised and promoted to generate income through attitude, values, skills and power of groups who work in an organisation (Danish, Asghar, Ahmad, \& Ali, 2019). Many argued that organisations with strong entrepreneurial culture have a high propensity to achieve growth and success (Kang, Matusik, Kim, \& Phillips, 2016; Danish et al., 2019). However, the meaning of the concept is neither well-defined nor constituted properly enough to foster entrepreneurial culture (Malecki, 2018). In Malaysia, it is evident that entrepreneurship culture was promoted to reduce or eliminate some of the significant social issues such as drug trafficking, crime, violence, and sexual offense among the youth (Kadir \& Merican, 2017). The launch of Malaysian Social Enterprise Blueprint 2015-2018, a three-year-long strategic plan for developing social enterprises through the formation of MAGIC SE to mandate social-economic growth in Malaysia with a fund of RM 20 mln was one of the initiatives to cultivate entrepreneurial culture (Malaysia Social Enterprise Blueprint, 2015). Another foundation was the Social Enterprise Alliances Malaysia (SEA) under MAGIC SE, with its own incubating program that fosters connections between social entrepreneurs and industry experts (Punadi \& Rizal, 2017).

Therefore, the role of education institution plays an important role in cultivating entrepreneurial culture among students. Students who graduated from these institutions tend to become entrepreneurs that solve social and other developmental issues of the country's economy (Bergmann, Geissler, Hundt, \& Grave, 2018). In the past, academic literature reported that academic institutions promote entrepreneurial culture through empowerment, by encouraging students to engage in risk-taking behaviours, and through various academic projects, networking, industry-based training, and related curriculum activities (Klofsten, Fayolle, Guerrero, Mian, Urbano, \& Wright, 2019). In terms of research, there was an increasing number of entrepreneurial research to legitimate research domain of entrepreneurial culture, about which many believed that lacks a theoretical foundation (Amina \& Zohri, 2019). Maroufkhani, Wagner, and Ismail (2018) argue that entrepreneurial cultural research is lacking in depth and inclusion of such research as a 'novel' area. Such novel areas of entrepreneurship research face the underdevelopment of concepts (Cavallo, Ghezzi, \& Balocco, 2019). Moreover, entrepreneurial cultural concepts are often challenged because of the changing demands of society and economy (Lange \& Schmidt, 2020). Since the entrepreneurial culture concept is still considered new in the field of entrepreneurship research, there are many opportunities for future research (Nikolova-Alexieva \& Angelova, 2020), and so, we identified many research and knowledge gaps.

The entrepreneurship field never covered well in the past how factors such as risk-taking behaviour, creativity, innovation, and empowerment motivate institutions to cultivate entrepreneurial culture (Ahmetoglu, Akhtar, Tsivrikos, \& Chamorro-Premuzic, 2018). Thus, studying how cultivating risktaking behaviour, innovation, creativity, and empowerment among students is considered to be one of the most rewarding research areas in the study of entrepreneurship (Müller, 2016). This is the research gap that can particularly be observed within the area of entrepreneurial culture and, therefore, many researchers propose to focus more on internal factors that promote entrepreneurial culture ( $\mathrm{Ni}$ kolova-Alexieva \& Angelova, 2020). The capacity to promote entrepreneurial culture should be counterbalanced with all other perspectives that consider the context of research and integrate cultural approaches (Danish et al., 2019). Zollo, Laudano, Ciappei, and Zampi (2017) argue that factors which foster entrepreneurial culture are in many ways similar to commercial entrepreneurship.

From the methodological point of view, several gaps and limitations exist in previous research related to entrepreneurial culture due to the recent development of the concept (van Ewijk, 2018; Ratten, 2019). Firstly, research related to entrepreneurial culture remains largely descriptive and theoretical (Wennberg \& Anderson, 2020). The literature review by Fritsch and Wyrwich (2018) shows that scholars engage in writing conceptual articles compared to empirical studies. Secondly, most past empirical studies on entrepreneurial culture lack rigorous methods (Fritsch \& Wyrwich, 2018; Spigel, 2018). Thirdly, research on fostering entrepreneurial culture relies on various definitions and perspectives, which hinders comparisons among studies from the past (Letaifa \& Goglio-Primard, 2016). Fur- 
thermore, most research on entrepreneurial culture positions itself primarily in the public and governmental sector (Demircioglu \& Chowdhury, 2020). To overcome this, our study will be conducted among students who study at private higher education institutions (PHEIs) in Cyberjaya, Malaysia, and will examine student perception of whether academic institutions really promote entrepreneurial culture rather than just including an entrepreneurial curriculum.

Another relevance of this study would be for government policymakers and entrepreneurship practitioners. From a political standpoint, they might be able to promote entrepreneurial culture indirectly, by intervening in curriculum development and academic assessment or projects that students might undertake while studying. Moreover, this study can be of value to practitioners and business incubators in their efforts to scout, finance, and promote high-potential innovative start-ups. Furthermore, that that allocate their resources to empowering students. Therefore, this study addresses the gaps in research through the presentation of empirical evidence, particularly from Malaysia. We compiled the recent academic debates and reviews done through publications on initiatives that an academic institution can take to cultivate the entrepreneurial culture among students (Wu \& Zhu, 2017). Our research question is the following: Does risk-taking behaviour, encouraging innovation, creativity, and empowerment constitute entrepreneurial culture among students of PHEls in Malaysia?

To address the current research gaps discussed above, this research aims to examine the factors affecting the fostering of entrepreneurial culture among students in higher education institutions in Malaysia. To achieve this, this study sets the following objectives that will examine the effect of (1) promoting risk-taking behaviour, (2) encouraging creativity, (3) supporting innovation, and (4) empowering students at PHEls in fostering entrepreneurial culture.

The structure of this paper is as follows. Firstly, we briefly discuss the relevant literature on the hypothesised relationship between entrepreneurial culture and (nascent) entrepreneurship. Next, we describe our empirical research method and the data we use. We then present the regression results and discuss their outcomes. Finally, we present our conclusions, discuss the limitations of our study, and make suggestions for future research.

\section{LITERATURE REVIEW}

The concept of entrepreneurial culture refers to an organisational culture embodying and upholding entrepreneurial attributes and characteristics (Genoveva, 2019). In the past, entrepreneurial culture was defined as entrepreneurial attributes, values, and mindset (Brownson, 2013). To foster entrepreneurial culture, some propose the requirement of a mindset that craves for innovation, creativity, and risk-taking (Blideanu \& Diaconescu, 2018). Furthermore, entrepreneurial culture is seen as an element of national culture that facilitates the success of economic growth (Valliere, 2019). Entrepreneurial culture is to encourage risk-taking, innovation and creativity (Nikolova-Alexieva \& Angelova, 2020). The literature suggests that entrepreneurial culture is related to a number of positive organisational outcomes, such as generating new business and improving firm performance (Lee \& Chu, 2017).

Entrepreneurial culture among students is to be influenced by personality, motivation, and family background, besides the curriculum (Odă \& Florea, 2019). Students bring to universities their personalities and family backgrounds, along with personal motivations, which altogether fosters entrepreneurship culture (Genoveva, 2019). The university provides a specific context of curricula, rules, expectations, and norms of behaviour to cultivate entrepreneurial culture enabling the enhancement of student's attitude towards entrepreneurial intention (Seth, 2020). Since most of the literature seeks to define entrepreneurial culture by merging together the two key terms 'entrepreneurship' and 'culture', entrepreneurial culture is usually to consist of independence, creativity, ambition, and courage (Kirkley, 2016). This research posits that to cultivate entrepreneurial culture, PHEls must encourage students to engage in risktaking behaviour, encourage creativity, support innovation, and promote empowerment.

There are various theories that attempt to define and conceptualise entrepreneurial culture. The entrepreneurship competency model has become an increasingly popular means of learning entrepreneurial characteristics (Schneider \& Albornoz, 2018). Regardless of a substantial number of studies in relation to entrepreneurial competencies, problems in relation to the competency improvement process 
and fostering entrepreneurial culture are generally neglected, as are key variables such as the need for achievement, internal locus of control, innovativeness, risk-taking propensity, and also tolerance of ambiguity were not covered in the competency model (Schneider \& Albornoz, 2018). On the other hand, psychological theories of entrepreneurship emphasise that promoting risk-taking, innovativeness, need for achievement, and tolerance for ambiguity were found to have positive and important control on entrepreneurial tendency (Embi, Jaiyeoba, \& Yussof, 2019). Alternatively, economic approaches of entrepreneurship also proposed to cultivate entrepreneurial culture by promoting capitalism where entrepreneurs obtained support to become successful in their ventures (Trivedi, 2016). However, economic approaches to entrepreneurship received noteworthy criticism for failing to distinguish the self-motivated, open personality of market systems, disregarding the distinctive personality of entrepreneurial activity and downplaying the various frameworks in which entrepreneurship occurs (Gurova \& Morozova, 2018).

Based on the review of the concept and related theories or approaches, this study reviewed various articles published in the field to formulate their own hypotheses. Scholars find that risk-taking behaviour among students studying at Malaysian PHEls encourages them to become entrepreneurs (Tunkarimu \& Hassan, 2017). Another study shows that risk-taking behaviour among the students promotes entrepreneurial intention to cultivate entrepreneurial culture in Malaysia (Embi et al., 2019). Since risk-taking propensity is described as a person's existing predisposition to seek or evade risks (Shamsudin, Al Mamun, Nawi, Nasir, \& Zakaria, 2017), PHEls could apparently teach their students the best way to deal with an entrepreneurial way of thinking and acting through assessments and group work (Embi et al., 2019; Gelaidan \& Abdullateef, 2017). This approach promotes risk-seeking states of mind to cultivate entrepreneurial culture among the students at PHEls in Malaysia (Embi et al., 2019; Gelaidan \& Abdullateef, 2017; Martins, Monsalve, \& Martinez, 2018). Moreover, encouraging students to engage in risktaking behaviour leads them to start new business ventures after graduation or, at least, their intention to become an entrepreneur is high (Llanos-Contreras, Alonso-Dos-Santos, \& Ribeiro-Soriano, 2019).

H1: Encouraging risk-taking behaviour among students cultivates entrepreneurial culture.

Past literature calls innovation a concept that involves the implementation of new ideas, improved products, processes, marketing methods, or business practices (Usulu \& Kedikli, 2019). Scholars show that innovation culture prevails among students, but also promotes entrepreneurial spirit and intention among PHEls in Malaysia (Lee, Kim, \& Sung, 2019; Tunkarimu \& Hassan, 2017). Furthermore, students with innovative personalities tend to engage in more entrepreneurial activities (Lee et al., 2019; Chuah, Ting, Run, \& Cheah, 2016). Institutions that facilitate knowledge transfer and spillovers cause students to engage with innovative behaviour, which results in entrepreneurial culture (Block et al., 2017; Xu \& Maas, 2019). Others find that entrepreneurial culture is important to foster innovation and improve performance (Leal-Rodríguez, Albort-Morant, \& Martelo-Landroguez, 2017). It is important to implement a learning process from information embedded in external networks, which drives innovation to cultivate entrepreneurial culture among PHEIs (Baker, Grinstein, \& Harmancioglu, 2016). Similarly, ambidextrous orientation and innovation strategy enhance innovation and cultivates entrepreneurial culture (Hanifah, Halim, Ahmad, \& Vafaei-Zadeh, 2019). Moreover, students with a high level of innovation tend to incline towards entrepreneurial thinking (Mohamad, Abdullah, Ishak, \& Hashim, 2019) and cultivating entrepreneurial culture. Therefore, we hypothesise that:

H2: Encouraging innovation among students will cultivate entrepreneurial culture.

Creativity among employees and team members is important to foster entrepreneurial culture within the organisation (Cai, Lysova, Khapova, \& Bossink, 2019). Leader's creativity motivates teams and employees to engage with creative behaviour and cultivate an entrepreneurial orientation (Cai et al., 2019). Similarly, in the educational context, teacher's creativity inspires students to engage in entrepreneurial activities to cultivate entrepreneurial culture among PHEls (Wibowo \& Saptono, 2018). Scholars find that creativity has significant effect on student's entrepreneurial thinking to cultivate entrepreneurial culture in Malaysia (Mohamed et al., 2019). However, the idea that creativity causes entrepreneurial culture is inconclusive and weak, as others find that teacher's creativity does not significantly influence entrepreneurial intention but influences entrepreneurial intention through entrepreneurial education (Wibowo \& Saptono, 2018). Since its teacher's creativity that motivates students 
to become entrepreneurs, some organisation implement 'Design Thinking' to cultivate entrepreneurial skills such as creativity and problem-solving abilities (Val, Gonzalez, Lauroba, \& Beitia, 2019; Wibowo \& Saptono, 2018). A systemic literature review shows that individual creativity causes entrepreneurial orientation among students to foster entrepreneurial culture (Rahim, Ismail, Thurasamy, \& Abd, 2018). Others report that creativity comprising of business ideas and high-quality business ideas has a significant influence on entrepreneurial orientation and intention, causing people to cultivate entrepreneurial culture (Shifaâ, Abd Razak, Kosnin, \& Buang, 2018). Therefore, we hypothesise that:

H3: Encouraging creativity among students will cultivate entrepreneurial culture.

Yet other scholars report that the empowerment of teachers has a positive relationship with entrepreneurial leadership and school effectiveness (Dahiru, Pihie, Basri, \& Hassan, 2017). Furthermore, they find that teacher's empowerment moderates the relationship between entrepreneurial leadership and school effectiveness (Dahiru et al., 2017). Country-level studies suggest that empowerment encourages people to get involved in entrepreneurial activities such as starting or owning a small or medium-sized enterprise (SME; Digan, Sahi, Mantok, \& Patel, 2019). Another study found that empowerment is the key to foster an entrepreneurial ecosystem among societies, including vulnerable groups (Margaret, Anese, \& Emmanuel, 2019). Similarly, others argue that empowerment is important to cultivate and foster entrepreneurial culture within organisations (Henao-Zapata \& Peiró, 2018). In the Malaysian context, studies find that empowerment among the youth and students leads to entrepreneurial development that cultivates entrepreneurial culture (Taha, Ramlan, \& Noor, 2017). Another study in the Malaysian context reveals that encouraging empowerment among students motivates cultivating entrepreneurial culture, which results in entrepreneurial intention (Basit, Sing, \& Hassan, 2018). Therefore, we hypothesise that:

H4: Increasing empowerment among students will cultivate entrepreneurial culture.

\section{RESEARCH METHODOLOGY}

\section{Research paradigm}

Among the key research approaches - exploratory, descriptive, and explanatory research - the most appropriate conduct in hypothesis analysis is considered to be explanatory research (Saunders, 2011). To conduct the research proposed above, the most appropriate research paradigm (research patterns that this proposed research will follow) will be positivism, because of the following reasons:

- the researchers will directly involve themselves in observation, and they will base their findings on the perceived value of the respondents who are not familiar with the phenomenon;

- positivism emphasises empirical methods in verifying the subject of the investigation;

- this research emphasises investigating the entrepreneurial elements that constitute entrepreneurial culture.

\section{Research methods}

\section{Target population and sampling}

The target population consisted of students at private higher education institutions (PHEIs) in Cyberjaya, Malaysia. We distributed 300 questionnaires among the target population. The sample size was determined based on the items in the item construction. Initially, there were 21 items to measure the four dimensions of entrepreneurial culture and five items to measure entrepreneurial culture. After the first-order confirmatory factor analysis (CFA), one item (Item1) was removed from the dimension of risk-taking behaviour and one item from creativity in order to obtain the required fitness through confirmatory factor analysis and normality test. Therefore, the required sample size was 250 , and this study managed to collect data from 256 respondents using the convenient sampling technique, as it is easy and convenient to collect data from student populations studying in Cyberjaya, Malaysia. The detailed profile of the respondents is illustrated in Table 1 below. 
Table 1. Respondent's profile

\begin{tabular}{|c|c|c|c|c|c|}
\hline \multicolumn{2}{|c|}{ Characteristics } & \multirow{2}{*}{\begin{tabular}{r|} 
Frequency \\
121 \\
\end{tabular}} & \multirow{2}{*}{\begin{tabular}{r|} 
Percent \\
47.3 \\
\end{tabular}} & \multirow{2}{*}{$\begin{array}{r}\text { Valid Percent } \\
47.3 \\
\end{array}$} & \multirow{2}{*}{$\begin{array}{r}\begin{array}{l}\text { Cumulative } \\
\text { Percentage }\end{array} \\
49.6 \\
\end{array}$} \\
\hline \multirow{3}{*}{ Gender } & Female & & & & \\
\hline & Male & 129 & 50.4 & 50.4 & 100.0 \\
\hline & Total & 256 & 100.0 & 100.0 & \\
\hline \multirow{5}{*}{ Age (years) } & $>=50$ & 2 & .8 & .8 & 3.1 \\
\hline & $18-24$ & 95 & 37.1 & 37.1 & 40.2 \\
\hline & $25-35$ & 85 & 33.2 & 33.2 & 73.4 \\
\hline & $36-49$ & 68 & 26.6 & 26.6 & 100.0 \\
\hline & Total & 256 & 100.0 & 100.0 & \\
\hline \multirow{3}{*}{ Marital Status } & Married & 99 & 38.7 & 38.7 & 41.0 \\
\hline & Single & 151 & 59.0 & 59.0 & 100.0 \\
\hline & Total & 256 & 100.0 & 100.0 & \\
\hline \multirow{5}{*}{ Qualification } & Bachelors & 136 & 53.1 & 53.1 & 55.5 \\
\hline & Diploma & 65 & 25.4 & 25.4 & 80.9 \\
\hline & Masters & 30 & 11.7 & 11.7 & 92.6 \\
\hline & Others & 19 & 7.4 & 7.4 & 100.0 \\
\hline & Total & 256 & 100.0 & 100.0 & \\
\hline
\end{tabular}

Source: own study.

\section{Measures}

The survey instrument had 24 items, grouped into five categories. Four independent factors that constituted entrepreneurial culture comprise risk-taking behaviour (five items), creativity encouragement (four items), support of innovation (five items), and empowerment (five items). The dependent factor was entrepreneurial culture, which is measured with five items, as shown in Table 3 below. The normality of the scale was measured using kurtosis and skewness. We considered data distribution to be normal if skewness and kurtosis fell out of the range of -1 to 1 . The reliability of the scale was considered acceptable if the Cronbach's alpha values were above 0.7 (Hair et al., 2010). Since most of the values fell under the range of normality, data distribution was considered to be normal. Table 2 shows the reliability of the scale. The overall means were also reliable as the standard deviation was lower than 1 , which suggested that the mean value was not deviant from central tendency. The correlation was not very high or very low, suggesting that there were no multi-correlations.

Table 2. Item construction

\begin{tabular}{|c|c|c|c|c|}
\hline Dimension & Items & Loading & $\begin{array}{l}\text { Cronbach' } \\
\text { s Alpha }\end{array}$ & AVE \\
\hline \multirow{5}{*}{$\begin{array}{l}\text { Risk-Taking } \\
\text { Behaviour }\end{array}$} & $\begin{array}{l}\text { Students may express their opinions and views in various meet- } \\
\text { ing held between students and staff }\end{array}$ & 0.600 & \multirow{5}{*}{0.715} & \multirow{5}{*}{0.593} \\
\hline & $\begin{array}{l}\text { Students are encouraged to complain about their dissatisfaction } \\
\text { towards teachers and other issues }\end{array}$ & 0.670 & & \\
\hline & $\begin{array}{l}\text { Students receive a guarantee that marks and other grading will } \\
\text { not be affected when they complain about teachers or manage- } \\
\text { ment issues }\end{array}$ & 0.517 & & \\
\hline & $\begin{array}{l}\text { Students are motivated to take risk by receiving challenging } \\
\text { tasks such as unique projects }\end{array}$ & 0.562 & & \\
\hline & $\begin{array}{l}\text { Institution provides rooms for students to develop decision- } \\
\text { making skills and capabilities }\end{array}$ & 0.616 & & \\
\hline \multirow{2}{*}{$\begin{array}{l}\text { Creativity } \\
\text { Encourage- } \\
\text { ment }\end{array}$} & $\begin{array}{l}\text { My teachers and the management of the institution take stu- } \\
\text { dent questions seriously to foster creativity }\end{array}$ & 0.723 & \multirow[b]{2}{*}{0.769} & \multirow[b]{2}{*}{0.706} \\
\hline & $\begin{array}{l}\text { My teachers and the management of the institution promote } \\
\text { self-evaluation among the student during class presentation and } \\
\text { other related assessments to promote individual creativity }\end{array}$ & 0.652 & & \\
\hline
\end{tabular}




\begin{tabular}{|c|c|c|c|c|}
\hline Dimension & Items & Loading & $\begin{array}{l}\text { Cronbach' } \\
\text { s Alpha }\end{array}$ & AVE \\
\hline & $\begin{array}{l}\text { My teachers and the management of the institution promote } \\
\text { creativity through problem-solving }\end{array}$ & 0.789 & & \\
\hline & $\begin{array}{l}\text { My teachers and the management of the institution encourage } \\
\text { the generation of new ideas through rewards and appreciation }\end{array}$ & 0.661 & & \\
\hline \multirow{5}{*}{$\begin{array}{l}\text { Support } \\
\text { of Innova- } \\
\text { tion }\end{array}$} & $\begin{array}{l}\text { My teachers and the management of the institution encourage } \\
\text { me to engage in innovative behaviors by exploring opportuni- } \\
\text { ties, generating ideas, championing, and putting efforts in the } \\
\text { development of entrepreneurial skill }\end{array}$ & 0.832 & \multirow{5}{*}{0.819} & \multirow{5}{*}{0.674} \\
\hline & $\begin{array}{l}\text { My teachers and the management of the institution acts friendly } \\
\text { to innovative students, being patient, helpful, listening, and } \\
\text { looking out for students' interests if problems arise }\end{array}$ & 0.596 & & \\
\hline & $\begin{array}{l}\text { My teachers and the management of the institution show appre- } \\
\text { ciation for innovative performance made by students }\end{array}$ & 0.715 & & \\
\hline & $\begin{array}{l}\text { My teachers and the management of the institution teaches stu- } \\
\text { dents to come up with ideas and to evaluate current practices } \\
\text { directly }\end{array}$ & 0.704 & & \\
\hline & $\begin{array}{l}\text { My teachers and the management of the institution provides finan- } \\
\text { cial material rewards for innovative performances by students }\end{array}$ & 0.534 & & \\
\hline \multirow{5}{*}{$\begin{array}{l}\text { Empower- } \\
\text { ment } \\
\text { Encourage- } \\
\text { ment }\end{array}$} & $\begin{array}{l}\text { My teachers and the management of the institution give me free- } \\
\text { dom to make my own decisions on how to complete my tasks }\end{array}$ & 0.647 & \multirow{5}{*}{0.729} & \multirow{5}{*}{0.592} \\
\hline & $\begin{array}{l}\text { My teachers and the management of the institution delegate re- } \\
\text { sponsibilities during extracurricular activities such as sports }\end{array}$ & 0.562 & & \\
\hline & $\begin{array}{l}\text { My teachers and the management of the institution encourage } \\
\text { me to study and complete assessments independently with min- } \\
\text { imal supervision or guidance }\end{array}$ & 0.531 & & \\
\hline & $\begin{array}{l}\text { My lecturers and the management of the institution attempt to } \\
\text { build trust among students and teachers }\end{array}$ & 0.650 & & \\
\hline & $\begin{array}{l}\text { My teachers and the management of the institution encourage } \\
\text { students to take full responsibility and accountability for their } \\
\text { actions and outcomes of their actions. }\end{array}$ & 0.568 & & \\
\hline \multirow{5}{*}{$\begin{array}{l}\text { Entrepre- } \\
\text { neurial } \\
\text { culture }\end{array}$} & $\begin{array}{l}\text { The study environment of the institution promotes the inde- } \\
\text { pendence of students }\end{array}$ & 0.543 & \multirow{5}{*}{0.834} & \multirow{5}{*}{0.709} \\
\hline & $\begin{array}{l}\text { The study environment of the institution promotes aggressive } \\
\text { competition among students to receive high marks }\end{array}$ & 0.641 & & \\
\hline & $\begin{array}{l}\text { The current study environment of the institution promotes pro- } \\
\text { activeness among students }\end{array}$ & 0.768 & & \\
\hline & $\begin{array}{l}\text { The current study environment of the institution promotes inno- } \\
\text { vation among student through innovative idea generation }\end{array}$ & 0.801 & & \\
\hline & $\begin{array}{l}\text { The current study environment of the institution promotes risk- } \\
\text { taking behavior among students through challenging and en- } \\
\text { couraging the expression of their own opinions }\end{array}$ & 0.793 & & \\
\hline
\end{tabular}

Source: adapted from Jong and Hartog (2007), Marandi et al. (2015), Alshut (2007), and Sharma (2015).

Validity

The validity of items on the scale was tested using average variance extracted (AVE) and factor loadings. Two validity tests were carried out such as convergent and discriminant validity by using confirmatory factor analysis via AMOS. Factor loadings on each item exceeded 0.5, which suggested that all items in the item construction were valid. Also, in terms of AVE on each dimension in the construction was above 0.5 , which suggested that it was valid.

In terms of discriminate validity, it was important to show that variables are not related or strongly related to each other. Table 3 epresents the discriminant validity outcomes. 
Table 3. Discriminant validity

\begin{tabular}{|l|l|l|l|l|l|}
\hline \multirow{2}{*}{\multicolumn{1}{c|}{ Variables }} & \multicolumn{6}{c|}{ Correlation } \\
\cline { 2 - 6 } & \multicolumn{1}{c|}{$\mathbf{1}$} & \multicolumn{1}{c|}{$\mathbf{2}$} & \multicolumn{1}{c|}{$\mathbf{3}$} & \multicolumn{1}{c|}{$\mathbf{4}$} & \multicolumn{1}{c|}{$\mathbf{5}$} \\
\hline 1: RISKTAKING & 1 & 0.487 & 0.487 & 0.183 & 0.182 \\
\hline 2: CREATIVITY & 0.698 & 1 & 0.745 & 0.384 & 0.362 \\
\hline 3: INNOVATION & 0.698 & 0.863 & 1 & 0.403 & 0.392 \\
\hline 4: EMPOWER & 0.428 & 0.62 & 0.635 & 1 & 0.429 \\
\hline 5: ENTERCULTURE & 0.427 & 0.602 & 0.626 & 0.655 & 1 \\
\hline
\end{tabular}

Note: The squared correlation is above the diagonal (1)

Source: own study.

The items in the construct were discriminantly valid, as the squared correlation values were lower and the overlapping of the correlation was minimal. Since the squared correlation above the diagonal was lower than 0.5 , it was considered discriminant valid. Another way to test the existence of discriminant validity is to check whether the AVE values are higher than the squared correlation values. In this case, the AVE values were higher than all the squared correlation, which was above the diagonal, suggesting that the items used in the item construct were discriminately valid and there is no overlapping. In other words, the correlation coefficient was lower than 0.9 (Backhause et al., 2006).

\section{Analysis Techniques}

In this research, validity was examined using convergent and discriminant validity and confirmatory factor analysis via AMOS22. The reliability and normality of the scale were examined using Cronbach alpha values via SPSS. Similarly, a normality test was conducted using skewness and kurtosis via descriptive statistical analysis. The hypothesis or causal effect of the four elements of entrepreneurship was tested to examine its effect on entrepreneurial culture using structural equation modelling (SEM) via AMOS.

\section{RESULTS AND DISCUSSION}

\section{Structural equation modelling}

In order to proceed with the structural equation modelling (SEM), it is important to assess the model validity and reliability using model fitness indices. To assess the SEM model fitness, CFI, RMSEA, normed Chi-square were used. This means the CFI value must exceed 0.9 , the RMSEA value must be below 0.08 , and the normed chi-square must be less than 3 . As Figure 1 shows the CFI value was 0.902 , which exceeds 0.9, RMSEA value was 0.061 , which was below 0.08 and normed chi-square was 1.935, which was less than 3 suggesting that the SEM was a good fit model to proceed with path analysis (Hair et al., 2014; Hu \& Bentler, 1999).

Similarly, the validity of the SEM model was examined by comparing both model factor loadings. Table 4 below suggested that the SEM model is valid as the loading on each item under the CFA and SEM was exactly alike. Based on Hair et al. (2014), if the loading values are similar, SEM is deemed to be a valid model to analyse path estimates. 


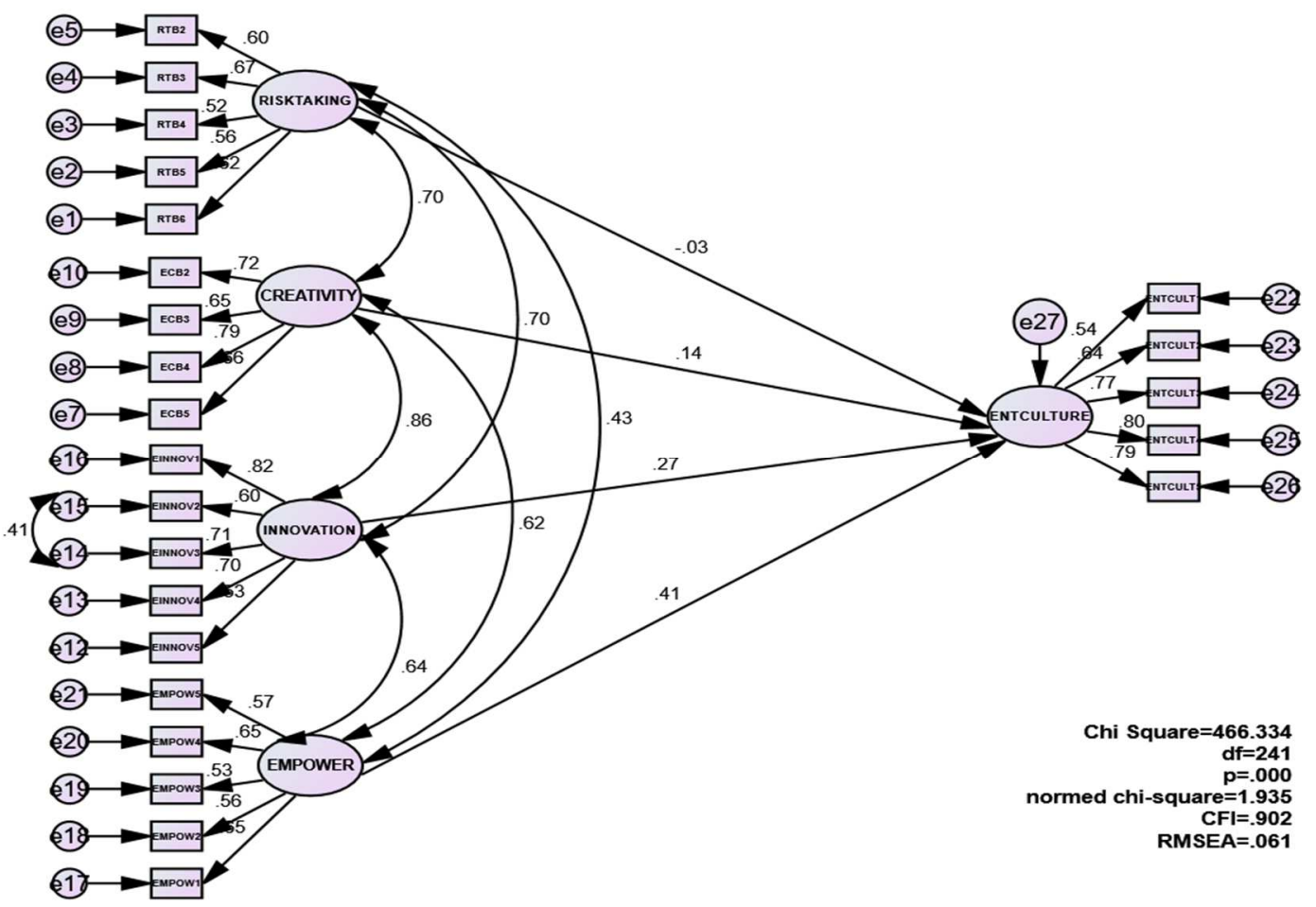

Figure 1. SEM-elements that constitute entrepreneurial culture Source: own elaboration using Amos graphics.

Table 4. The validity of SEM

\begin{tabular}{|l|c|c|c|}
\hline \multicolumn{1}{|c|}{ Variables } & Construct & Measurement Model & Structural Model \\
\hline RTB2 & Risktaking & 0.600 & 0.600 \\
\hline RTB3 & Risktaking & 0.670 & 0.670 \\
\hline RTB4 & Risktaking & 0.517 & 0.517 \\
\hline RTB5 & Risktaking & 0.562 & 0.562 \\
\hline RTB6 & Risktaking & 0.616 & 0.616 \\
\hline ECB2 & Creativity & 0.723 & 0.723 \\
\hline ECB3 & Creativity & 0.652 & 0.652 \\
\hline ECB4 & Creativity & 0.789 & 0.789 \\
\hline ECB5 & Creativity & 0.661 & 0.661 \\
\hline EINNOV1 & Innovation & 0.823 & 0.823 \\
\hline EINNOV2 & Innovation & 0.596 & 0.596 \\
\hline EINNOV3 & Innovation & 0.715 & 0.715 \\
\hline EINNOV4 & Innovation & 0.704 & 0.704 \\
\hline EINNOV5 & Innovation & 0.534 & 0.534 \\
\hline EMPOW1 & Empower & 0.647 & 0.647 \\
\hline EMPOW2 & Empower & 0.562 & 0.562 \\
\hline EMPOW3 & Empower & 0.531 & 0.531 \\
\hline EMPOW4 & Empower & 0.650 & 0.650 \\
\hline EMPOW5 & Empower & 0.568 & 0.568 \\
\hline ENTCULT1 & EntCulture & 0.543 & 0.543 \\
\hline ENTCULT2 & EntCulture & 0.641 & 0.641 \\
\hline ENTCULT3 & EntCulture & 0.768 & 0.768 \\
\hline ENTCULT4 & EntCulture & 0.801 & 0.801 \\
\hline ENTCULT5 & EntCulture & 0.793 & 0.793 \\
\hline EOTC:OWn & & & \\
\hline
\end{tabular}

Source: own study. 


\section{Hypothesis and path estimates}

Table 5 clearly shows that the only critical and significant element of entrepreneurship in cultivating entrepreneurial culture is empowerment as the $p$-value was 0.0001 , which was lower than the required $p<0.05$ (Hair et al., 2014). The stimulate value of 0.414 suggested that with the increase in one unit of empowerment, overall entrepreneurial culture existence in the academic institution will increase by 0.414 . It is important to note that innovation, creativity, and risk-taking behaviour have been found to have a positive and significant influence on entrepreneurial intention in the past. However, we found that these factors do not contribute to the cultivation of entrepreneurial culture among PHEls in Cyberjaya Malaysia.

Table 5. Hypotheses and path estimates

\begin{tabular}{|c|c|c|c|c|c|}
\hline Hypotheses & Estimate & S.E. & C.R. & P & Accept/Reject \\
\hline ENTCULTURE <--- RISKTAKING (H1) & -0.032 & 0.083 & -0.290 & 0.772 & Reject \\
\hline ENTCULTURE <--- CREATIVITY (H2) & 0.136 & 0.121 & 0.747 & 0.455 & Reject \\
\hline ENTCULTURE <--- INNOVATION (H3) & 0.268 & 0.145 & 1.426 & 0.154 & Reject \\
\hline ENTCULTURE <--- EMPOWER (H4) & 0.414 & 0.092 & 3.744 & $0.000^{* *}$ & Accept \\
\hline
\end{tabular}

${ }_{* *} p<0.01$ Significant level, ${ }^{*} p<0.05$ significant level

Source: own study.

\section{Discussion}

In general, studies report that the government of Malaysia through its constitutional bodies is playing a crucial role in developing and encouraging homegrown business entrepreneurs. Three of the most important institutions in this regard are the Ministry of Entrepreneur and Cooperative Development (MECD), its agency Perbadanan Nasional Berhad (PNS), and the SME Bank (Yusof, Jabar, Murad, \& Ortega, 2017). Therefore, efforts have been intensified and policies were drafted by the Malaysian government to encourage entrepreneurial activities and promote the growth of self-employment nationwide through small businesses, petty trading, agriculture, and services (EPU, 2006; Yusof et al., 2017). The Ministry of Higher Education and the Ministry of Entrepreneurship and Corporative Development (MECD) initiated several programs to foster entrepreneurial culture, such as the Young Entrepreneurship program, which was designed to promote the awareness of entrepreneurial activities among secondary school graduates (Norasmah \& Faridah, 2010). Another program is the Undergraduate Entrepreneur Development Programme (PPUS), designed for students of higher education institutions (Norasmah \& Faridah, 2010). The Undergraduate Entrepreneurship Training was also initiated by the government of Malaysia to promote entrepreneurial culture among undergraduates (Norasmah \& Farid, 2010). Similarly, the government of Malaysia formulated policies to ensure entrepreneurial curriculum was built into degree programs' syllabi. Therefore, our research focused on higher education institutions and the initiatives they have taken to promote the essential elements that constitute entrepreneurial culture such as risk-taking behaviour, encouraging innovation creativity, and empowerment among students studying at PHEls in Malaysia.

Based on the above information, our research attempted to find the effect of risk-taking behaviour, innovation, creativity, and empowerment on entrepreneurial culture. Our findings show that encouraging risk-taking behaviour among the students does not have a significant influence on the fostering of entrepreneurial culture, which contradicts Embi et al. (2019). Moreover, Llanos-Contreras et al. (2019) argue that encouraging students to engage in risk-taking behaviour leads them to initiate new business ventures and tend to cultivate entrepreneurial culture. However, our study does not establish this in the Malaysian PHEls context. Therefore, the statistical data generated for this study shows that encouraging risk-taking behaviour is not a major element in the institutions of Malaysia for cultivating entrepreneurship culture as its significance value is found to be 0.772 . Hence, H1 is rejected. 
In terms of innovation, we found that encouraging innovation among the students of PHEls in Cyberjaya, Malaysia, does not foster or encourage students to engage in an entrepreneurial ecosystem. Despite many argue that innovation should be an agenda of PHEls to promote entrepreneurial activities among these students. Our findings differ from past studies by Koellinger (2008) and Block et al. (2017). Such differences may stem from specific institutions and people who govern and study in these intuitions. As highlighted earlier, in order to foster an effective entrepreneurial culture, organisations must encourage the transformation of people and the environment by encouraging people to engage in innovative behaviour (Xu \& Maas, 2019). Furthermore, it is challenging and difficult for small academic institution who offer only diploma or undergraduate programs to facilitate innovation through networking as big or large companies only seeks to build networks with big universities who offer postgraduate degree programs (Baker et al., 2016). The findings for this study signify that encouraging creativity is also not a prominent reason in the institutions of Malaysia for cultivating entrepreneurship culture as the significance value is found to be 0.455 . Hence, $\mathrm{H} 2$ is rejected.

In terms of creativity initiatives and policies implemented by PHEIs, we found that they do not motivate students to engage in entrepreneurial activities, while the fostering of entrepreneurial culture at the institutions is mainly attributed to the presence of teacher's innovative behaviour, bound by regulatory rules and guidelines (Wibowo \& Saptono, 2018). Even though some studies suggest that teachers play an important role, student's family background and the level of studies and assessment are what appears to cultivate entrepreneurial culture (Cai et al., 2019). Similar to our finding, past research indicates that teachers' creativity does not have any significant influence on entrepreneurial intention or orientation (Wibowo \& Saptono, 2018). This means that innovative behaviour is not the main driver of cultivating entrepreneurship culture as the significance value is found to be 0.154 . Hence, $\mathrm{H} 3$ is rejected.

The only factor that showed a positive and significant effect on cultivating entrepreneurial culture in our study was empowerment. To promote empowerment, PHEls and the government of Malaysia encourage factors related to entrepreneurial creativity such as 'taking the question seriously,' 'encourage self-evaluation', 'creative problem-solving', and 'idea generation' through a greater degree of empowerment (Danish et al., 2019). In the context of our study, we may argue that PHEls in Cyberjaya, Malaysia, emphasise empowering teachers as it has a positive relationship with entrepreneurial leadership and school effectiveness (Dahiru et al., 2017). Since teacher's empowerment moderates the relationship between entrepreneurial leadership and school effectiveness (Dahiru et al., 2017), this suggests that empowerment encourages people to get involved with entrepreneurial activities such as owning or starting small and medium-sized enterprise (SME; Digan et al., 2019). Moreover, empowerment is the key to fostering an entrepreneurial ecosystem among societies, including vulnerable groups (Margaret et al., 2019). Therefore, empowerment is considered crucial in the cultivation of entrepreneurial culture within PHEls (Henao-Zapata \& Peiró, 2018). The findings of this study indicate that empowerment is the only factor in the proposed framework that cultivates entrepreneurship culture among the Malaysian PHEIs, as the significance value is found to be 0.000 . Hence, $\mathrm{H} 4$ is accepted.

\section{CONCLUSIONS}

Overall, we conclude that enhancing and encouraging empowerment among the students and teachers can cultivate entrepreneurial culture within PHEls in Malaysia. Moreover, we conclude that risktaking behaviour, creativity, and innovation do not necessarily foster entrepreneurial culture among students of PHEls in Cyberjaya, Malaysia. Based on our findings, we conclude that risk-taking behaviour, creativity, and innovation can be enhanced through empowerment to cultivate entrepreneurial culture. The most important factor to facilitate risk-taking behaviour, creativity, and innovation is empowerment given to the teachers and students of the PHEls. Furthermore, empowerment is the key to cultivate entrepreneurial culture, along with risk-taking behaviour and innovation.

\section{Theoretical and practical implications}

The current entrepreneurial culture or ecosystem prevail among the PHEls in Cyberjaya, Malaysia, with an emphasis on innovation through research technology transfer and collaborative research to foster 
entrepreneurial culture (Villani, Rasmussen, \& Grimaldi, 2017). Some of the PHEls 'act not only as educators but also as institutional entrepreneurs, proactively networking, shaping regional strategies and attempting to change local routines as well as national policies' (Raagmaa \& Keerberg, 2017, p. 270). Taking part in entrepreneurial activities organised by the government and communities encourages students to partake in this and increase the intention to become entrepreneurs. Some PHEls have engaged very much in incorporating an entrepreneurial curriculum in their syllabi and forming entrepreneurial clubs to organise related weekly events. This has promoted networking, idea generation, and taking-risk among students to invest in products and school projects. The success of such projects is measured by risk-taking behaviour, creativity, innovation, and return on investment.

Our study will assist or guide academic institutions to design and formulate entrepreneurial policies so as to encourage teachers and students to actively engage in entrepreneurial activities resulting in entrepreneurial culture or ecosystem. Moreover, this study will guide academic institutions to design human resources development policies through empowerment and delegation strategies so as to foster entrepreneurial culture among staff and academic leaders. This study will also play an important role for regulatory bodies to formulate policies and regulations that facilitate PHEIs to design curriculums and assessments that better foster entrepreneurial culture. Academic managers and policymakers should be careful in using innovation and creativity campaigns among students to cultivate entrepreneurial culture as they may waste resources without proper empowerment policies and commitment.

\section{Limitations}

However, our study shows the following limitations. Firstly, the study focused on very limited PHEIs in Cyberjaya, so generalising this study to all Malaysian PHEls may not be appropriate. Secondly, the selection of samples from the target population was not conducted very systematically. The respondents should be unique in terms of social status and exposure. The use of diploma, degree, and Master's level students coming from various backgrounds would vary the opinions of respondents on how PHEls carry their strategies in cultivating entrepreneurial culture. Finally, the academic institution's environment and curriculum were not considered in the item construction.

\section{Future research directions}

This study could be improved by employing a more systematic sampling method, which would allow a focus on matured postgraduate students. Moreover, it would be important to focus on selecting only students who come from the same income or social group, rather than taking vulnerable groups in the initial studies. Furthermore, this study can be improved by considering the study environment, institution-related factors, and curricula. Finally, it is important to consider institutional environment and policies as variables to the study and their effect on entrepreneurial culture.

\section{REFERENCES}

Acs, Z., Åstebro, T., Audretsch, D., \& Robinson, D.T. (2016). Public policy to promote entrepreneurship: a call to arms. Small Business Economics, 47(1), 35-51. https://doi.org/10.1007/s11187-016-9712-2

Adair, J.E. (2007). The art of creative thinking: How to be innovative and develop great ideas. London and Philadelphia: Kogan Page Publishers.

Ahmetoglu, G., Akhtar, R., Tsivrikos, D., \& Chamorro-Premuzic, T. (2018). The entrepreneurial organization: The effects of organizational culture on innovation output. Consulting Psychology Journal: Practice and Research, 70(4), 318-338. https://doi.org/10.1037/cpb0000121

Amina, A., \& Zohri, A. (2019). Entrepreneurial Culture and the Education System: The Case of Moroccan Universities. In 7th International OFEL Conference on Governance, Management and Entrepreneurship: Embracing Diversity in Organisations. April 5th-6th, 2019, Dubrovnik, Croatia (pp. 367-380). Zagreb: Governance Research and Development Centre (CIRU).

Ariffin, A.S., Baqutayan, S.M.S., \& Mahdzir, A.M. (2018). Enhancing women entrepreneurship development framework: Policy \& institution gap and challenges in the case of Malaysia. Journal of Science, Technology and Innovation Policy, 3(2), 1-12. 
Baker, W.E., Grinstein, A., \& Harmancioglu, N. (2016). Whose innovation performance benefits more from external networks: entrepreneurial or conservative firms?. Journal of Product Innovation Management, 33(1), 104-120. https://doi.org/10.1111/jpim.12263

Basit, A., Sing, M., \& Hassan, Z. (2018). Factors affecting entrepreneurship intention among the students in private sector of Malaysia. International Journal of Education, Learning \& Training, 3(2), 42-64. https://doi.org/10.24924/ijelt/2018.11/v3.iss2/42.64

Bergmann, H., Geissler, M., Hundt, C., \& Grave, B. (2018). The climate for entrepreneurship at higher education institutions. Research Policy, 47(4), 700-716. https://doi.org/10.1016/j.respol.2018.01.018

Beugelsdijk, S. (2007). Entrepreneurial culture, regional innovativeness and economic growth. Journal of Evolutionary Economics, 17(2), 187-210. https://doi.org/10.1007/s00191-006-0048-y

Block, J.H., Fisch, C.O., \& Van Praag, M. (2017). The Schumpeterian entrepreneur: A review of the empirical evidence on the antecedents, behaviour and consequences of innovative entrepreneurship. Industry and Innovation, 24(1), 61-95. https://doi.org/10.1080/13662716.2016.1216397

Brownson, C.D. (2013). Fostering entrepreneurial culture: a conceptualization. European Journal of Business and Management, 5(31), 146-155.

Bygrave, W.D., \& Hunt, S.A. (2005). Global Entrepreneurship Monitor: 2004 Financing Report. Retrieved from https://ssrn.com/abstract=1509264 on April 3, 2020.

Cai, W., Lysova, E.I., Khapova, S.N., \& Bossink, B.A. (2019). Does entrepreneurial leadership foster creativity among employees and teams? The mediating role of creative efficacy beliefs. Journal of Business and Psychology, 34(2), 203-217. https://doi.org/10.1007/s10869-018-9536-y

Cavallo, A., Ghezzi, A., \& Balocco, R. (2019). Entrepreneurial ecosystem research: present debates and future directions. International Entrepreneurship and Management Journal, 15(4), 1291-1321. https://doi.org/10.1007/s11365-018-0526-3

Chuah, F., Ting, H., Run, E.C., \& Cheah, J.H. (2016). Reconsidering what entrepreneurial intention implies: The evidence from Malaysian University students. International Journal of Business and Social Science, 7(9), 85-98. Retrieved from http://www.ijbssnet.com/journals/Vol_7_No_9_September_2016/10.pdf on April 1, 2020.

Coulibaly, S.K., Erbao, C., \& Mekongcho, T.M. (2018). Economic globalization, entrepreneurship, and development. Technological Forecasting and Social Change, 127, 271-280. https://doi.org/10.1016/j.techfore.2017.09.028

Dahiru, A.S., Pihie, Z.A.L., Basri, R., \& Hassan, S.A. (2017). Mediating effect of teacher empowerment between entrepreneurial leadership and school effectiveness. The Social Sciences, 12(11), 2077-2084. https://doi.org/10.36478/sscience.2017.2077.2084

Danish, R.Q., Asghar, J., Ahmad, Z., \& Ali, H.F. (2019). Factors affecting 'entrepreneurial culture': the mediating role of creativity. Journal of Innovation and Entrepreneurship, 8(1), 1-12. https://doi.org/10.1186/s13731019-0108-9

Digan, S.P., Sahi, G.K., Mantok, S., \& Patel, P.C. (2019). Women's Perceived Empowerment in Entrepreneurial Efforts: The Role of Bricolage and Psychological Capital. Journal of Small Business Management, 57(1), 206229. https://doi.org/10.1111/jsbm.12402

Demircioglu, M.A., \& Chowdhury, F. (2020). Entrepreneurship in public organizations: the role of leadership behavior. Small Business Economics, 1-17. https://doi.org/10.1007/s11187-020-00328-w

Easterby-Smith, M., \& Thorpe, R. (1997). Research traditions in management learning. In Management Learning: Integrating Perspectives in Theory and Practice (pp. 38-53). London: Sage.

Embi, N.A.C., Jaiyeoba, H.B., \& Yussof, S.A. (2019). The effects of students' entrepreneurial characteristics on their propensity to become entrepreneurs in Malaysia. Education+ training, 61(7/8), 1020-1037. https://doi.org/10.1108/ET-11-2018-0229

Fritsch, M., \& Wyrwich, M. (2018). Regional knowledge, entrepreneurial culture, and innovative start-ups over time and space-an empirical investigation. Small Business Economics, 51(2), 337-353. https://doi.org/10.1007/s11187-018-0016-6

Gelaidan, H.M., \& Abdullateef, A.O. (2017). Entrepreneurial intentions of business students in Malaysia. Journal of Small Business and Enterprise Development, 4(1), 54-67. https://doi.org/10.1108/JSBED-06-2016-0078 
Genoveva, G. (2019). The Influence of Entrepreneurial Culture on Entrepreneurial Intention Among Business Students. FIRM Journal of Management Studies, 4(1), 40-56. Retrieved from http://e-journal.president.ac.id/presunivojs/index.php/FIRM-JOURNAL/article/download/682/404 on April 2, 2020.

Gurova, O., \& Morozova, D. (2018). Creative precarity? Young fashion designers as entrepreneurs in Russia. Cultural Studies, 32(5), 704-726. https://doi.org/10.1080/09502386.2018.1428646

Hanifah, H., Halim, H.A., Ahmad, N.H., \& Vafaei-Zadeh, A. (2019). Emanating the key factors of innovation performance: leveraging on the innovation culture among SMEs in Malaysia. Journal of Asia Business Studies, 13(4), 559-587. https://doi.org/10.1108/JABS-04-2018-0130

Hair Jr, J.F., Sarstedt, M., Hopkins, L., \& Kuppelwieser, V.G. (2014). Partial least squares structural equation modeling (PLS-SEM). European Business Review, 26(2), 106-121. https://doi.org/10.1108/EBR-10-2013-0128

Hair, J.F., Black, W.C., Babin, B.J., \& Anderson, R.E. (2010). Multivariate Data Analysis. Seventh Edition. Upper Saddle River, New Jersey: Prentice Hall.

Henao-Zapata, D., \& Peiró, J.M. (2018). The importance of empowerment in entrepreneurship. In Inside the Mind of the Entrepreneur (pp. 185-206). Cham: Springer.

Henry, C., Hill, F., \& Leitch, C. (2017). Entrepreneurship education and training: the issue of effectiveness: the issue of effectiveness. London: Routledge. https://doi.org/10.4324/9781315197227

Kadir, S.A., \& Merican, R.M.B.A.R. (2017). Factors Influencing Entrepreneurial Intention Among Malaysian Youth. International Journal of Accounting, Finance and Business, 2, 33-48.

Kirkley, W.W. (2016). Entrepreneurial behaviour: the role of values. International Journal of Entrepreneurial Behavior \& Research, 22(3), 290-328. https://doi.org/10.1108/IJEBR-02-2015-0042

Klofsten, M., Fayolle, A., Guerrero, M., Mian, S., Urbano, D., \& Wright, M. (2019). The entrepreneurial university as driver for economic growth and social change-Key strategic challenges. Technological Forecasting and Social Change, 141, 149-158. https://doi.org/10.1016/j.techfore.2018.12.004

Koellinger, P. (2008). Why are some entrepreneurs more innovative than others?. Small Business Economics, 31(1), 21. https://doi.org/10.1007/s11187-008-9107-0

Lange, B., \& Schmidt, S. (2020). Entrepreneurial ecosystems as a bridging concept? A conceptual contribution to the debate on entrepreneurship and regional development. Growth and Change: A Journal of Urban and Regional Policy (Special Issue), 1-18. https://doi.org/10.1111/grow.12409

Lee, T., \& Chu, W. (2017). The relationship between entrepreneurial orientation and firm performance: Influence of family governance. Journal of Family Business Strategy, 8(4), 213-223. https://doi.org/10.1016/j.jfbs.2017.09.002

Lee, J., Kim, D., \& Sung, S. (2019). The Effect of Entrepreneurship on Start-Up Open Innovation: Innovative Behavior of University Students. Journal of Open Innovation: Technology, Market, and Complexity, 5(4), 103. https://doi.org/10.3390/joitmc5040103

Letaifa, S.B., \& Goglio-Primard, K. (2016). How does institutional context shape entrepreneurship conceptualizations?. Journal of Business Research, 69(11), 5128-5134. https://doi.org/10.1016/j.jbusres.2016.04.092

Leal-Rodríguez, A.L., Albort-Morant, G., \& Martelo-Landroguez, S. (2017). Links between entrepreneurial culture, innovation, and performance: The moderating role of family firms. International Entrepreneurship and Management Journal, 13(3), 819-835. https://doi.org/10.1007/s11365-016-0426-3

Llanos-Contreras, O., Alonso-Dos-Santos, M., \& Ribeiro-Soriano, D. (2019). Entrepreneurship and risk-taking in a post-disaster scenario. International Entrepreneurship and Management Journal, 1-17. https://doi.org/10.1007/s11365-019-00590-9

Malaysia Social Enterprise Blueprint 2015-2018: Unleashing the Power of Social Entrepreneurship. (2015). Cyberjaya, Selangor: Malaysian Global Innovation \& Creativity Centre (MaGIC).

Malecki, E.J. (2018). Entrepreneurship and entrepreneurial ecosystems. Geography Compass, 12(3), 1-21. https://doi.org/10.1111/gec3.12359

Maroufkhani, P., Wagner, R., \& Ismail, W.K.W. (2018). Entrepreneurial ecosystems: A systematic review. Journal of Enterprising Communities: People and Places in the Global Economy, 12(4), 545-564. https://doi.org/10.1108/JEC-03-2017-0025

Margaret, A.R., Anese, S.A., \& Emmanuel, F.O. (2019). Nigerian Women Empowerment and the Entrepreneurial Myth. Journal of Modern Accounting and Auditing, 15(9), 453-464. https://doi.org/10.17265/1548$6583 / 2019.09 .004$ 
Martins, I., Monsalve, J.P.P., \& Martinez, A.V. (2018). Self-confidence and fear of failure among university students and their relationship with entrepreneurial orientation. Academia Revista Latinoamericana de Administración, 1(3), 471-485. https://doi.org/10.1108/ARLA-01-2018-0018

Mohamad, A., Abdullah, S., Ishak, A.K., \& Hashim, N. (2019). Entrepreneurship Education as a Way of Cultivating Entrepreneurial Thinking among Students of Malaysian Public Higher Learning Institutions. International Journal of Social Science and Humanity, 9(4), 97-102. https://doi.org/10.18178/ijssh.2019.9.4.998

Müller, S. (2016). A progress review of entrepreneurship and regional development: What are the remaining gaps?. European Planning Studies, 24(6), 1133-1158. https://doi.org/10.1080/09654313.2016.1154506

Nikolova-Alexieva, V., \& Angelova, M.N. (2020). Opportunities for raising the entrepreneurial culture-a factor for competitiveness of the Bulgarian economy. International Journal of Entrepreneurship and Small Business, 40(3), 373-398.

Norasmah, O., \& Faridah, K. (2010). Entrepreneurship Behaviour amongst Malaysian University Students. Pertanika Journal of Social Sciences \& Humanities, 18(1), 23-32.

Raagmaa, G., \& Keerberg, A. (2017). Regional higher education institutions in regional leadership and development. Regional Studies, 51(2), 260-272. https://doi.org/10.1080/00343404.2016.1215600

Rahim, A.W.P.A., Ismail, W.K.W., Thurasamy, R., \& Abd, I. (2018). The relationship of individual creativity with entrepreneurial intention via individual entrepreneurial orientation (IEO). International Journal of Innovation and Business Strategy, 9(1), 41-54. Retrieved from https://business.utm.my/ijibs/attachments/article/96/IJIBS_09_01_04.pdf on April 1, 2020.

Ratten, V. (2019). Older entrepreneurship: a literature review and research agenda. Journal of Enterprising Communities: People and Places in the Global Economy, 3(1/2), 178-195. https://doi.org/10.1108/JEC-08-2018-0054

Renne Pramila, P., \& Adriana, M.R. (2017). Factors that cultivate youth intention to be social entrepreneur. International Journal of Innovation and Business Strategy, 8(2), 1-10.

Shamsudin, S.F.F.B., Al Mamun, A., Nawi, N.B.C., Nasir, N.A.B.M., \& Zakaria, M.N.B. (2017). Factors affecting entrepreneurial intention among the Malaysian university students. The Journal of Developing Areas, 51(4), 423-431. https://doi.org/ 10.1353/jda.2017.0111

Saunders, M.N. (2011). Research methods for business students. 5 ed. Pearson Education India.

Schneider, K., \& Albornoz, C. (2018). Theoretical model of fundamental entrepreneurial competencies. Science Journal of Education, 6(1), 8-16. https://doi.org/10.11648/j.sjedu.20180601.12

Seth, P.K. (2020). The impact of entrepreneurship education on entrepreneurial intention: An empirical study of entrepreneurship education's four key characteristics (Doctoral dissertation, Brunel University London). Retrieved from_http://bura.brunel.ac.uk/handle/2438/20368 on April 2, 2020.

Shifaâ, N., Abd Razak, N.B., Kosnin, H.B., \& Buang, N.A.B. (2018). The Influence of Creativity towards Entrepreneurial Intention and the Entrepreneurial Career Choice Behaviour in 21st Century Learning. The Journal of Social Sciences Research, [Special Issue 6], 45-51. https://doi.org/10.32861/jssr.spi6.45.51

Spigel, B. (2018). Envisioning a new research agenda for entrepreneurial ecosystems: Top-down and bottom-up approaches. In J.A. Katz \& A.C. Corbett (Eds.), Reflections and Extensions on Key Papers of the First TwentyFive Years of Advances (pp. 127-147). Emerald Publishing Limited. https://doi.org/10.1108/S1074754020180000020004

Taha, K.A.S., Ramlan, S.N., \& Noor, I.M. (2017). The factors affecting entrepreneurial intentions of university students in Malaysia. International Journal of Business and Technopreneurship, 7(2), 189-202. Retrieved from https://ijbt.unimap.edu.my/images/stories/VOL\%207,\%20No.\%202,\%20JUN\%202017/IJBT_Vol_7_Jun_2017_6_189-202.pdf on April 3, 2020.

Tunkarimu, T.I., \& Hassan, Z. (2017). Entrepreneurial characteristics among local \& foreign students studying in Malaysia: The role of gender. International Journal of Education, Learning \& Training, 2(1), 12-27. https://doi.org/10.24924/ijelt/2017.04/v2.iss1/12.27

Trivedi, R. (2016). Does university play significant role in shaping entrepreneurial intention? A cross-country comparative analysis. Journal of Small Business and Enterprise Development, 23(3), $790-811$. https://doi.org/10.1108/JSBED-10-2015-0149

Uslu, Y.D., \& Kedikli, E. (2019). The Importance of Entrepreneurship and Innovation Management in Terms of Modern Businesses. International Journal of Academic Value Studies, 5(1), 1-11. Retrieved from https://www.researchgate.net/publication/331166798 on April 3, 2020. 
Val, E., Gonzalez, I., Lauroba, N., \& Beitia, A. (2019). How can Design Thinking promote entrepreneurship in young people?. The Design Journal, 22(sup1), 111-121. https://doi.org/10.1080/14606925.2019.1595853

Valliere, D. (2019). Refining national culture and entrepreneurship: the role of subcultural variation. Journal of Global Entrepreneurship Research, 9(47), 1-22. https://doi.org/10.1186/s40497-019-0172-4

Van Ewijk, A. (2018). Persistence and Acuteness of Research Gaps in Entrepreneurship Education: A Systematic Content Analysis of Previous Reviews (1987-2017). International Journal of Entrepreneurship, 22(2), 1-18. Retrieved from https://dspace.adu.ac.ae/handle/1/1584 on April 1, 2020.

Van der Westhuizen, T. (2017). A Systemic Approach towards Responsible and Sustainable Economic Development: Entrepreneurship, Systems Theory, and Socio-Economic Momentum. In T. Van der Westhuizen (Ed.). Entrepreneurship: Concepts, Methodologies, Tools, and Applications (pp. 429-447). IGI Global. https://doi.org/10.4018/978-1-5225-1823-5.ch011

Vodă, A.I., \& Florea, N. (2019). Impact of personality traits and entrepreneurship education on entrepreneurial intentions of business and engineering students. Sustainability, 11(4), 1192. https://doi.org/10.3390/su11041192

Villani, E., Rasmussen, E., \& Grimaldi, R. (2017). How intermediary organizations facilitate university-industry technology transfer: A proximity approach. Technological Forecasting and Social Change, 114, 86-102. https://doi.org/10.1016/j.techfore.2016.06.004

Weber, M., \& Camerer, C. (1987). Recent developments in modelling preferences under risk. Operations-Research-Spektrum, 9(3), 129-151. https://doi.org/10.1007/BF01721094

Wennberg, K., \& Anderson, B.S. (2020). Enhancing the exploration and communication of quantitative entrepreneurship research. Journal of Business Venturing, 35(3), 1-11 https://doi.org/10.1016/j.jbusvent.2019.05.002

Wennekers, S., \& Thurik, R. (1999). Linking entrepreneurship and economic growth. Small Business Economics, 13(1), 27-56. https://doi.org/10.1023/A:1008063200484

Wibowo, A., \& Saptono, A. (2018). Does Teachers' Creativity Impact on Vocational Students' Entrepreneurial Intention?. Journal of Entrepreneurship Education, 21(3), 1-12.

Wu, Z.W., \& Zhu, L.R. (2017). Cultivating innovative and entrepreneurial talent in the higher vocational automotive major with the 'on-board educational factory' model. Eurasia Journal of Mathematics, Science and Technology Education, 13(7), 2293-2300. https://doi.org/10.12973/eurasia.2017.00746a

Xu, Z., \& Maas, G. (2019). Innovation and Entrepreneurial Ecosystems as Important Building Blocks. In Maas G., \& Jones P. (Eds.), Transformational Entrepreneurship Practices (pp. 15-32). Cham: Palgrave Pivot. https://doi.org/10.1007/978-3-030-11524-12

Yusof, S.W.M., Jabar, J., Murad, M.A., \& Ortega, R.T. (2017). Exploring the cultural determinants of entrepreneurial success: The case of Malaysia. International Journal of Advanced and Applied Sciences, 4(12), 287-297. https://doi.org/10.21833/ijaas.2017.012.048

Zollo, L., Laudano, M.C., Ciappei, C., \& Zampi, V. (2017). Factors affecting universities' ability to foster students' entrepreneurial behaviour. Journal of Management Development, 36(2), 268-285. https://doi.org/10.1108/JMD-06-2016-0093 


\section{Authors}

Zubair Hassan formulated the research concept, research problems, the rationale, and he contributed written research methodology and analysis (50\%). Muneeb Khan designed the research instrument and data collection (30\%). Abdul Basit proofed the readings and edited the text and citation, he also wrote the conclusion, recommendations, and research implications sections (20\%).

\section{Zubair Hassan}

PhD Scholar in Business Administration (2020, International Islamic University, Malaysia); Master's in Public Policy and Management (2009, Monash University, Australia); Bachelor of Business Administration (2005, Northumbria University, the United Kingdom). His research interests include organisational behaviour, entrepreneurship, leadership, marketing, teaching methods, and strategy.

Correspondence to: Zubair Hassan (PhS Scholar), Head of Department, IUMW Business School International University of Malaya-Wales, Level 2, Block A, City Campus, Jalan Tun Ismail, 50480 Kuala Lumpur, Malaysia Email: Zubai7@gmail.com

ORCID (1) http://orcid.org/0000-0003-3552-3146

\section{Muneeb Khan Lashari}

Master's in Business Administration (2017, Anglia Ruskin University, UK); Bachelor of Science in Accounting and Finance (2016, Anglia Ruskin University, UK). His research interests include mergers and acquisitions, finances, and entrepreneurship.

Correspondence to: Muneeb-Khan Lashari (MBA graduate), PG alumnae, Anglia Ruskin University, Cambridge, UK. Email: Muneeblashari92@gmail.com

ORCID (1) http://orcid.org/0000-0001-5543-4293

\section{Abdul Basit}

PhD Scholar in Business (2020, International University of Malaya-Wales, Malaysia); Master's in Business Administration (2017, Anglia Ruskin University, UK); Bachelor of Science in Accounting and Finance (2016, Anglia Ruskin University, UK). His research interests include capital structure, finance marketing and branding, leadership, and customer perceived values.

Correspondence to: Abdul Basit (PhD Scholar), Member of Teaching, Learning and Research committee, IUMW Business School, International University of Malaya-Wales, Level 2, Block A, City Campus, Jalan Tun Ismail, 50480 Kuala Lumpur, Malaysia Email: abdulbasit9037@gmail.com

ORCID (1) http://orcid.org/0000-0001-5410-9237

\section{Acknowledgements and Financial Disclosure}

There was no financial aid or sponsorship for this study. Any cost incurred were borne by the authors during data collection and proofreading.

\section{Conflict of Interest}

The authors declare that the research was conducted in the absence of any commercial or financial relationships that could be construed as a potential conflict of interest.

\section{Copyright and License}

This article is published under the terms of the Creative Commons

Attribution - NoDerivs (CC BY-ND 4.0) License

http://creativecommons.org/licenses/by-nd/4.0/ 
